Roman Sukač

\title{
TRACING THE PRODIGAL SON'S VOYAGE
}

\author{
Václavovi
}

\section{Abstract}

The author completes Blažek's extensive etymological analysis of the Indo-European word for 'son'. The article focuses on the behavior of the word from the accentological and paradigmatic point of view in Balto-Slavic and separate Slavic languages.

\section{KEYWORDS}

*suHnus; Proto-Indo-European; Balto-Slavic; Proto-Slavic; accentuation; morphology; paradigmatic cases; case endings

\section{Introduction}

Blažek $(2008,2010)$ dealt extensively with the etymology of the Indo-European word *suHnus. The purpose of my article is to track the historical journey of *suHnus from the accentological and morphological point of view from Balto-Slavic languages. The son's travel was seemingly not comfortable.

\section{Son in his accentual labyrinth}

For the original accentual reconstruction, the Balto-Slavic and Old Indic forms are essential. Old Indic shows the final stress sūnús (EWA II, 741). The first problem connected with the Balto-Slavic word for 'son' is its accentual mobility.

Lithuanian sūnùs belongs to the Lithuanian mobile paradigm $\mathrm{AP}_{3}$ where most cases are end-stressed apart from dative and accusative singular and nominative and acusative plural (sg.: sūnùs, sūnaũs, súnui, súnų... pl: súnūs, sūnū, sūnùms, súnus... The forms in $\mathrm{AP}_{3}$ did not undergo de Saussure's law in Lithuanian so the mobility 
must have risen differently. However, Daukša's Postilla has mostly barytonesis throughout the paradigm except for some doublets (KORTLANDT 2009, 89). ${ }^{1}$

The Balto-Slavic form was reconstructed by Derksen $(2008,483)$ as *sú?nus if we construe the original laryngeal ${ }^{*} \mathrm{H}$ as the glottal stop.

Slavic languages with pitch-accent patterns show the falling intonation: S-Cr. sin-sina, Sln. sîn-sina. The Proto-Slavic (PSl) form is reconstructed as a member of the accentual paradigm $c(\mathrm{APc})$ with circumflex intonation on the initial syllable in some inflectional cases and stem/ending stress in other cases.

The Proto-Indo-European (PIE) form is reconstructed as end-stressed *suH-nús (DERKSEN 2008, 483).

Scholars believe that Proto-Indo-European stress, which was free and mobile, lost its mobility in Balto-Slavic outside the nominal flexion of the consonant stems and became mostly columnal. However, consonant stems were the further source of mobility spreading in vocalic stems (KoRTLANDT 2009, 23).

The important fact concerning the word for 'son' is that it escaped Hirt's Law in Balto-Slavic. The Hirt's Law describes the relationship of the original root with a laryngeal and the stress: if the original root contained a laryngeal in the coda, the stress shifted leftwards from the neighboring syllable. The target syllable obtained acute, reflected in some forms of the accentual paradigm AP1 in Lithuanian and the immobile acute paradigm APa in Slavic. The original laryngeal root could have been a dominant morpheme in Balto-Slavic but recessive in Old Indic where stress remained at the stem syllable (see SuKAČ 2013, 136-158) for the detailed account of various explanations of Hirt's Law). The typical examples are, e.g. PIE *dhuH-mós 'smoke', OInd. dhūmá, Lith. dúmai, S-Cr. dïm, Cz. dým, PSl. dy̋mъ (APa); PIE *griHuáH 'mane', OInd. grīvá 'neck', S-Cr. grïva, Cz. hř́vva, PSl. * grivva (APa). Thus *suH-nús behaves anomalously here because we should expect Lithuanian ** súnus ( $\mathrm{AP} 1), \mathrm{S}-\mathrm{Cr}$. ${ }^{* *}{ }^{*} \ddot{n}, \mathrm{Cz} .{ }^{* *}$ sýn and PSl. ${ }^{* *}$ sÿnъ (APa). Hirt's Law would have caused the retraction of stress in the forms *suHnú- which would erase the original accentual mobility (KORTLANDT 2009, 88). So how to explain the unusual behavior of the Balto-Slavic "son"? We can adduce two solutions: the one by F. Kortlandt, another by J. Jasanoff.

According to Kortlandt $(2009,3,43)$, one of the first Balto-Slavic accentual law called Pedersen's Law caused that the ictus was retracted from stressed inner syllables in mobile paradigms of polysyllabic consonant stems followed by the analogical barytonesis in vocalic stems (acc. sg. súnų) and subsequent oxytonesis (e.g. nom. sg. sūnùs, dat. pl. sūnùms, inst. sg. sūnumì or inst. pl. sūnumis. The original accentuation was also preserved in the S-Cr. nom. sg. sin which later underwent Meillet's Law.

1 For reader's sake I mostly do not quote the original Kortlandt's papers which sometimes have different printed and internet versions (see www.kortlandt.nl). Some of them were even published several times with different pagination. Most of the important papers concerning Balto-Slavic accentology were published in Kortlandt (2009) without the original pagination. As this book of his selected papers is more accessible to the potential reader, I prefer to quote from it rather than from the original sources. 
Meillet's Law in Slavic is considered a kind of polarization pressure in mobile paradigms which would put the ictus in the root-accented forms as far from the end of the word as possible. The idea originally comes from Matasović $(2008,133)$. When we compare Lithuanian and Slavic stems of mobile paradigms, we observe that the Lithuanian stem can be acute, circumflex, or short. In Slavic, it is never acute, so mobilia do not have the acute. The word "son" is an example of a stem with Lithuanian acute forms, acc. sg. súnu but with the Slavic circumflex stem, like S-Cr. nom. sg. sin. As the root * suH-contains a laryngeal (which was probably glottal stop), the acute should be expected in Slavic. Because we find circumflex there, Kortlandt $(1975,11 ; 1983,7)$ proposes the analogical elimination of laryngeals in barytone forms of mobile paradigms. The absence of laryngeal yields circumflex (as reflected in S-Cr. sin). Therefore, the circumflex marks the lack of an original laryngeal in Slavic. On the other hand, the original presence of a laryngeal is reflected by acute intonation in Lithuanian forms. Chronologically, Meillet's Law belongs to Early Proto-Slavic and did not operate in Baltic. So any comparison of Slavic, Baltic or Greek circumflexes do not make sense.

According to Kortlandt, the Balto-Slavic oxytonesis must have preceded Hirt's Law, because it Lithuanian forms preserved it. So Hirt's Law did not occur in trisyllabic case forms of the form * suHnu-.

The "standard" theory which Kortlandt developed and advocated since the late 1970 s has changed. Kortlandt $(2009,105)$ rejected his earlier claims and proposes, that the final stress in the Lith. sūnùs appeared due to the generalization of final stress in the non-neuter nom. sg. forms, the Balto-Slavic barytonesis did not affect the acc. sg. form súnų and there was no Balto-Slavic oxytonesis which would affect the inst. sg. sūnumi which might reflect the original final stress. It is the fundamental turning point from claims which Kortland has advocated for many years.

The recent book by Jasanoff (2017) continues with his involvement in Balto-Slavic accentology and his distinctive interpretation of Balto-Slavic mobility origin. Jasanoff's conception was heavily criticized by Kortlandt. Apart from the discussions of general conceptions, the age-long clash mostly dissolves into the discussion of specific examples. Having refrained on the topic of the clash (for details see SukAč 2013, 129-131, 272-274), let's see how the fate of the "son" is interpreted by Jasanoff. His theory of the Balto-Slavic mobility uses the Saussure-Pedersen's Law (SPL; 2017, 122) which, in Jasanoff's idiosyncratic interpretation, generates the left-marginal accent, and Proto-Vasiljev-Dolobko's Law (PVDL; also Jasanoff's own concept, see 2017,128 ) which assigns a final accent to long forms in mobile paradigms. Jasanoff often contrasts the results of his theories with the theory of Balto-Slavic mobility problem by Olander (2009).

Concerning the Meillet's Law, Jasanoff $(2017,49)$ seems to take Meillet's Law as a simple four-part analogy and a phonological, rather than a morphological explanation. 
As for the Hirt's Law in Balto-Slavic, Jasanoff agrees that the PBS *suHnu- was already mobile before Hirt's Law with the final accent in forms like nom. sg. ${ }^{*} \mathrm{suH}$ nús and left-marginal accent in forms like acc. sg. *sùHnun (JASANOFF 2017, 107). Hirt's Law influenced the former form to *súHnus. According to Jasanoff (JaSANOFF $2017,107)$ this caused the paradigm * suHnus being immobile with anomalous accentuations *súHnus versus *sùHnun which required analogical repair which created a new mobile paradigm with alternating left-marginal and final accent. So *sùHnun remained but the forms affected by Hirt's Law analogically reverted to oxytonicity $>$ suHnús. The SPL creates the form *suHnùs, and the PBS form is *sūnùs giving the same form in Lithuanian (JASANOFF 2017, 133).

Other paradigmatic forms show a similar development. The genitive singular form is reconstructed from the PIE form *suHnéus > post-SPL *suhnèus > PBS *sūnèus $>$ Lith. sūnaũs (JASANOFF 2017, 133) On the background of his theory, Jasanoff can explain the development of more or less all the paradigmatic forms from PIE to Lithuanian and Proto-Slavic (JASANOFF 2017, 133-140).

However, apart from the fact that Jasanoff's explanation of the development is too mechanical, some accentual patterns are even explained by analogy e.g., PIE loc. sg. *suHnếu > Lith. sūnujè based on galvojè. To fit the theory, Jasanoff reconstructs even over-complicated forms like gen. pl. PIE suHnéuoHom undergoing the SPL *sùHneuoHon and PVDL *suHnounoHón and giving PBS *sūnovòn. However, this form is hardly expected to create the Lithuanian sūnũ but can continue to the PSl *synovọ with a surprisingly reconstructed nasalized yer (JASANOFF 2017, 149; for the explanation of his nasalized yers see JASANOFF 2017, 152).

As we can see, the behavior of the "son" from the accentological point of view is by no means easy, and the debate concerning the Balto-Slavic accentual mobility problem still continues.

\section{Son in the crooked mirrors of his own paradigm}

Thanks to Olander (2015) we now have a very detailed overview of the development of the Proto-Slavic nominal paradigms (although Olander's work mostly focuses on the development of endings). We can show the forms of "son" from PIE to Proto-Balto-Slavic (PBS), Lithuanian and Proto-Slavic (PSl) within the $u$-stem nominal paradigm: (adapted according to OLANDER 2015 and others with my remarks):

Nom. sg. PIE *suHnús > * sūnus > PBS *sūnus > Lith. sūnùs (original form is preserved), PSl * syn to *z; circumflex is due to the Meillet's Law). 
Gen. sg. PIE *suHnéus > * sūnéus > PBS *sūnáus > Lit. sūnaũs (circumflex is analogical according to $\bar{a}$-stems, see OLANDER 2015, 128); PSl *sŷnu (circumflex is due to the Meillets's Law; the ending *aus $>{ }^{*}$-ous with further narrowing to *-us $>^{*}-u$ (for a different explanation see OLANDER 2015, 128). The PBS gen. sg. endings *-aus, loc. sg. * $^{*} \mathrm{a} u$ and voc. sg. *-au are analogical (OLANDER 2015, 53) and are taken from the forms where short ${ }^{*} e$ is backed to *a before * ${ }^{*}$, like PIE nom. pl. *-eues > PBS *-aues $>\mathrm{PSl}{ }^{*}$-aue > -ove (OLANDER 2015, 52 with further references). This also counts for dative singular *-euei giving PS -ovi. It means that every *-eu changes to *au before any vowel (KoRTLANDT 2009, 33, also OLANDER 2015, 53 contra older views).

Dat. sg. PIE *suHn'euei > *sūn'euei > PBS *sūn'euei (*-euei > -auei, OLANDER 2015, 148) $>$ Lith. súnui (with o-stem ending, acute appeared probably from PBS barytonesis); PSl *ouei > *synovi.

Acc. sg. PIE *'suHnum > *'sūnum > PBS * sū'num (oxytonesis or Mobility Law in Olander's conception, OlANDER 2015, 116) > Lith. * súnu (barytonesis; *-um >ų), PSl *sŷnъ ( circumflex is due to the Meillet's Law; $\left.{ }^{*}-m>-0 ;{ }^{*}-u->-ъ\right)$.

Voc. sg. PIE *'suHneu > *'sūneu >PBS *sūn'au (oxytonesis; the ending *-au is analogical (KortLANDT 2009, 33; OLANDER 2015, 183) > Lith. sūnaũ; PSl *sŷnu < *au.

Loc. sg. PIE *suHnéu > *sūnéu > PBS *sūnāu (oxytonesis, analogical ending (OlanDER 2015: 173); Lith. sūnujè (the form based on analogy with i-stems, OlaNDER 2015, 173); PSl. *synù.

Inst. sg. PIE*suHnuh $>$ > PBS *sünumi (the original ending was replaced by -*umi from ${ }^{*}-u b^{h} i$ by substitution of ${ }^{*} b^{h}$ with ${ }^{*} m$ (OLANDER 2015, 162); Lith. sūnumì (the instrumental singular marker *-mi was taken from consonantal stems with final acute intonation (OLANDER 2015, 159); PSl *synı̀mb.

Nom. pl. PIE *suHnéues > *sūnues > PBS *sünaúes; according to Olander's conception of Mobility Law Olander $(2015,229)$ there should have been the accented ending. But the unaccentedness attested by Balto-Slavic languages can come from the 0 and $\bar{a}$ - stems). Alternatively, the Lithuanian form súnūs reflects PBS barytonesis. The Lithuanian ending -uss is probably the result of analogical influence from the acc. pl. (OLANDER 2015, 228-229 with further discussion); PSl *synove.

Gen. pl. PIE *suHneuom >* sūneuom > PBS *sūnauam; Lith. sūnũ. Olander $(2015,261)$ explains the Lithuanian ending from the PIE zero grade *-uom > PBS *-uam >-u with the substitution of *-om with *o-m from 0 -stems. Olander also thinks that the final accentuation is analogical. However, it might also have been the reflex of the PBS 
oxytonesis. But PSl accentuation is reconstructed as *synòvъ (loss of final yer gives long <ó> in Old Czech: synóv). The ending continues from the original full grade.

Acc. pl. PIE *suHnúms > *sūnúns > PBS *sü'nuns; Lith. súnus. According to Olander, in Lithuanian the ending attracted the stress by de Saussure's Law and was subsequently shortened by Leskien's Law. The acute intonation should have arisen phonetically at the pre-stage of Lithuanian in word final structures ended in *-ns (OlANDER 2015, 245-246). Olander's explanation is very problematic. First, he postulates the acute without any existence of laryngeal but on some unknown phonetic reasons; second, he does not explain the barytone form in the Lithuanian accusative plural. The Lithuanian accentuation could have appeared either by the early PBS barytonesis or (more probably) by Hirt's Law. PSl *sūnū >*sŷny.

Loc. pl. PIE *suHnusu > *sūnusu > PBS *sūnu'su; Lith. sūnuosè. Olander (2015, 290-291) with regards to other authors considers the Lithuanian ending an analogical innovation according to $o$-stems. The accentuation on the ending is due to PBS oxytonesis. PSl. ending in * synъchì reflects the RUKI rule.

Inst.pl. PIE * ${ }^{*} u H n u b{ }^{h} i_{2} h_{2}$ was replaced in PBS with * sūnuma (the ${ }^{*} b^{h} / m$ substitution, see OlANDER 2015, 217 with further discussion). Lith. sūnumis is probably influenced by $i$-stems with final oxytonesis. PSl form is *synzma with the probable final accentuation.

\section{Two and more prodigal sons are not the same}

The development of the "son" in the context of the fusion of 0 -stems and $u$-stems in different Slavic languages is very well-known and described elsewhere (e.g., STIEBER 1971, 22-32; TOWNSEND - JANDA 1996, 148-156)). The reason for the fusion and mutual influence of $o$ - and $u$-stems was mainly the rise of animacy and virility. There is no need to discuss all the range of paradigmatic cases. Let's pick just one case and use a magnifying glass to show how it behaves.

The nominative plural marker *-ove continues to all Slavic languages, but its distribution is limited by the morphological and semantic factors (STIEBER 1971, 
28). South Slavic languages use the ending -ove/-eve mainly for marking plural of monosyllable masculines: Bulg. sin - sinove, S-Cr sin - sïnovi, Slovene sín - sinóvi (with -ovi developed from the fusion of -ove and i-stem marker -i). In the North Slavic the distribution of -ove is limited mostly to the animate masculines. However, the ending is also contaminated with other plural markers as in other Slavic languages or underwent sound changes.

The Russian synovjá appeared as the fusion of -ove and -ja ending of soft stems. In the Upper Sorbian the ending -ojo in synojo continues from the original -ove which weakened to -ov́ >-ojo (STIEBER 1971, 18). The Slovak -ovia in synovia is the result of contamination of -ove with the collective *-bja >*-ia (like bratia 'brothers'). The original form synove occurs in the East Slovak territory (PAuliny 1990, 40). Old Polish has -owie: synowie from -ove due to the palatalization.

The Czech nom. pl. -ové contains long é which cannot be explained phonetically. Olander $(2015,229$ under the influence of TRÁVNíčEK 1935, 297) thinks that the long final vowel is taken from the $i$-stem. But it is not possible, because the original $i$ stem ending ${ }^{*}$-bje develops to -ie in Old Czech with the further narrowing to -i. On the other hand, the masculine i-stems take the long é: hostie/hosté. Vážný $(1963,78)$ explains this long ending -é as the contamination of the original consonantal ending and the length from -ie. It is true that the long -é can be found in some Old Czech o-stems with the original *-tel or -aninъ suffixes: kazatelé 'priests', prietelé 'friends', zeměné 'yeomen' but in Old Czech we do not find any plural marker with short -e in masculine consonantal stems. So where did the long -é in the ending come from?

Gebauer $(1960,49)$ sifted the evidence of the ending -ové in Old Czech and proposed that the long -é must be younger than the Czech é >i narrowing which took place from the 15 th to $17^{\text {th }}$ centuries (HMČ, 115). The é $>i$ narrowing operated only in Czech and Central Moravian dialects and did not affect the standard language much. So the form synové must have escaped narrowing and must be of more recent origin.

However, Old Czech also had the ending -ovie: kusovie 'pieces', kamenovie 'stones' which puzzled Gebauer so much that his explanation of the origin of the Old Czech -ovie ranges from the alleged -ove/-ie contamination to some unknown dialectal influence or simply scribes' errors (GEBAUER 1960, 49).

Focusing on the nominative plural form of "son", the situation in dialects puzzles us more: the form synove (short $e$ ) is typical for Czech and Silesian dialects. The Moravian dialects have mostly syni. The ending -ové appears always as a doublet, probably due to the influence of Standard Czech mostly in the East Czech territory, in the Czech towns and secondarily in the former Sudetenland due to the postWWII migration (ČJA 4, 155-156).

No convincing argument for the existence of -ové has been proposed so far. 


\section{Colophon}

Prodigal (adj.) - from Lat. prō 'forth' + agere 'drive'; indicates the quality of a person who, during some part of his life, drives forth his heritage. When the person reappears later, he is still recognizable but he looks different. Something new has happened to him.

That's what the prodigal son does in our story.

12 things you need to know about the Prodigal Son.

\section{REFERENCES}

BLAŽEK, Václav. 2010. Synové Indoevropanů. Linguistica Brunensia, 58(1-2), 93-120.

BLAŽEK, Václav. 2011. Indo-European *suHnu- "son" and its relatives. In: KRISCH, Thomas LINDNER, Thomas, eds. Indogermanistik und Linguistik im Dialog. Wiesbaden: Reichert Verlag.

ČJA 4 = BALHAR, Jan et. al. 2002. Český jazykový atlas 4. Praha: Academia.

DERKSEN, Rick. 2008. Etymological Dictionary of the Slavic Inherited Lexicon. Leiden: Brill.

ECKERT, Rainer - BukEvičIŪté, Elvira-Julia - HINZE, Friedhelm. 1994. Die baltischen Sprachen. Eine Einführung. Leipzig/Berlin/München: Verlag Langenscheidt - Verlag Enzyklopädie.

EWA = MAYRHOFER, Manfred. 1986-1996. Etymologisches Wörterbuch des Altindoarischen 1-2. Heidelberg - Winter.

Gebauer, Jan. 1960 Historická mluvnice jazyka českého. Díl II. Tvarosloví. I. Skloňování. Praha: NČAV.

HMČ = LAMPRECHT, Arnošt - ŠLOSAR, Dušan - BAUER, Jan. 1986. Historická mluvnice češtiny. Praha: SPN.

JaSAnOFf, Jay H. 2017. The Prehistory of the Balto-Slavic Accent. Leiden: Brill.

Kortlandt, Frederik. 1975. Slavic Accentuation. A Study in Relative Chronology. Lisse: The Peter de Ridder Press.

KoRTLANDT, Frederik. 1983. Linguistic theory, universals, and Slavic accentuation. Folia Linguistica Historica 4, 27-43.

KoRTLANDT, Frederik. 2009. Baltica \& Balto-Slavica. Leiden: Rodopi.

MatAsović, Ranko. 2008. Poredbeno povijesna gramatika Hrvatskoga jezika. Zagreb: Matica Hrvatska.

OlANDER, Thomas. 2009. Balto-Slavic accentual mobility. Berlin: de Gruyter.

OlANDER, Thomas. 2015. Proto-Slavic Inflectional Morphology. Leiden: Brill.

PAuliny, Eugen. 1990. Vývin slovenskej deklinácie. Bratislava: Veda.

STIEBER, Zdzisław. 1971. Zarys gramatyki porównawczej języków słowiańskich. Część II. Zeszyt 1. Fleksja imienna. Warszawa: Państwowe wydawnictwo naukowe.

SukAČ, Roman. 2013. Introduction to Proto-Indo-European and Balto-Slavic Accentology. Newcastle upon Tyne: Cambridge Scholars Publishing.

Townsend, Charles - JAnda, Laura A. 1996. Common and Comparative Slavic: Phonology and Inflection. Bloomington, IN: Slavica Publishers, Inc. 
TRÁVNÍČEK, František. 1935. Historická mluvnice československá. Praha: Melantrich.

VÁžNÝ, Václav. 1963. Historická mluvnice česká II. Tvarosloví. 1. část. Skloňování. Praha: SPN. www.ncregister.com/blog/jimmy-akin/12-things-you-need-to-know-about-the-prodigal-son.

\section{Roman Sukač}

Institute of the Czech language and Library Science

Silesian University in Opava, Faculty of Philosophy and Science

Masarykova tř́́da 343/37, 746 o1 Opava

Czech Republic

roman.sukac@fpf.slu.cz 
